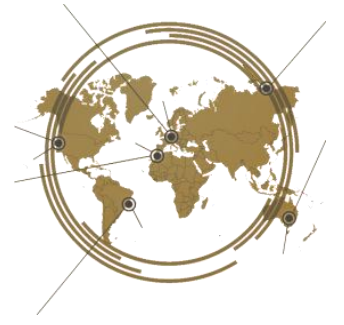

\title{
Online assessment strategies to enhance EFL students' competence and their implementational challenges
}

\author{
Ida Ayu Made Sri Widiastuti, ${ }^{+1}$ Ida Bagus Nyoman Mantra, ${ }^{1}$ Heru Sukoco, ${ }^{2}$ Made Hery \\ Santosa ${ }^{3}$
}

${ }^{1}$ Universitas Mahasaraswati Denpasar, Indonesia, ${ }^{2}$ Institut Pertanian Bogor, Indonesia, ${ }^{3}$ Universitas Pendidikan Ganesha, Indonesia

Education is a key to a successful life for all human beings. Having a good education certainly helps people to have a better life and improve their living standard. Therefore, education should be continually conducted meaningfully to enhance students' competence. However, carrying out effective learning and appropriate classroom assessment during the coronavirus pandemic could be highly challenging for the teachers to do. Teachers need to utilize various technological devices to assess students' learning competence. This is due to online learning has become a priority in learning activities in the pandemic situation. Consequently, teachers must have broader horizons on how to conduct the learning processes and appropriate assessment strategies and operate various communication technologies. This study found that English teachers implemented three types of online assessment strategies to improve students' learning competence during the pandemic of Covid-19 in Indonesia. Those strategies are online test administration, portfolio, and self-assessment. Several challenges were accoutered by the teachers in carrying out the classroom assessment through online systems such as slow internet network, expensive internet quota prices, limited access to computer and smartphone devices, poor ability in using digital technology, and difficulty in conducting effective interaction. Feedback was occasionally provided when the learning processes were conducted through zoom meeting or google meet. The study implies that teachers should improve their communication technology ability and fulfill online assessment strategies' administrative procedures.

OPEN ACCESS

ISSN 25033492 (online)

${ }^{*}$ Correspondence. Ida Ayu Made Sri Widiastuti

idaayuwidia@unmas.ac.id

Received: 28th April 2021 Accepted: 19th October 2021 Published: 20th October 2021

Citation: Widiastuti, I.A.M.S, Mantra, I.B.N., Sukoco, H. \& Santosa, M.H. (2021). Online assessment strategies to enhance students' competence and their implementational challenges.

J. Eng. Educ. Society. 6:2. doi:10.21070/jees.v6i2.1378
Keywords: assessment, strategies, competence, challenges

\section{INTRODUCTION}

Along with the advancement of science and technology, educational processes have moved towards more sophisticated and independent strategies because it allows open communication to occur in a distant location. The educational process in 21 st-century society is an interaction between teachers and students in accordance with advances in communication technology that become more democratic as in an open community. Besides, as teachers, sufficient competence must be possessed to carry out the tasks of teaching, guiding, fostering, and directing students to have excellent, motivated, and noble character. This is a difficult task for the teachers to do. There are many skills and competencies that should be enriched to be highly professional teachers (Mantra et al., 2019). Therefore, there are several challenges faced by the teachers in conducting their duties nowadays. 
Furthermore, teachers must be able to conduct appropriate assessments to assess the students' competence suited to the competence needed to live in a 21st-century society (Ma \& Gao, 2010). Therefore, higher skills are needed by teachers to make their students gain higher thinking skills.

High-quality assessments can create students to think more deeply about the subject matter (Baleni, 2015). It can be said that through the assessment of higher-order thinking skills, students can more easily develop their thinking skills. Therefore, assessments should be conducted to ensure improvements in learning competence and thinking skills. Moreover, in a broader sense, teachers are expected to always follow the development of the education system and as assessment systems, both science and technology must be mastered to keep up with the current needs of the students (Wang, 2018). This implies that teachers should be technically minded. This is one of the characteristics of $21 \mathrm{st}-$ century society. The 21 st century is marked by the presence of various types of internet instruments and facilities in the world of education that provides many conveniences and choices in order to support the learning process (Alruwais, Wills \& Wald, 2018).

Technology plays an important role in updating conventional learning to technology-based learning. Technological developments can change a person in learning, both to obtain information and present information in a good and complex manner (Alruwais, Wills \& Wald, 2018). Teachers can use technology to conduct better online assessments. Assessment is a process or an effort to obtain much information about students' development during learning activities as material in decision making by teachers to improve the students' learning outcomes and improve the upcoming learning process. Assessment activities are an integral component of teaching and learning activities (Robles \& Braathen, 2002). An assessment of learning outcomes needs to obtain information about the achievement of results from students' learning process by predetermined goals. Besides, the implementation of the assessment enables teachers to provide feedback to students to improve their competence.

In practice, assessment is the process of gathering information and processing information to measure students' learning outcomes (Kearns, 2012). Moreover, it is also used to determine the strengths and weaknesses of the learning process to be used as the basis for decision-making in modifying learning strategies so that the upcoming learning process is more effective. The assessment process under normal conditions certainly does not require a special strategy to be mastered by teachers. However, the process of classroom assessment during the current pandemic requires the ability of teachers to design appropriate assessment process strategies because the assessment process is carried out indirectly or online (Gamage, et.al, 2020). Teachers are forced to conduct online assessments to avoid direct contact with their students. Assessment and evaluation carried out at home are carried out by teachers through remote assessment methods or distance assessment practices (Sewell, Frith \& $\underline{\text { Colvin, 2010). }}$
Therefore, in addition to suitable assessment strategies and good and well-planned assessment systems, the ability of assessment technology is also needed (Cakiroglu et al., 2017a).

In educational practices, the rapid development and advancement of technology today enable teachers to be more creative in teaching because of the availability of communication technology. Moreover, online assessment becomes easier to be carried out, especially with the existence of the internet network (Timmis et al., 2016). Teachers can take advantage of application media connected to the internet network to assess and evaluate learning outcomes online. However, in Indonesia, problems in implementing online assessment are merely related to limited accessibility and poor internet connection or online network unavailability. To solve these obstacles, various efforts were undertaken by the education stakeholders to ensure that assessment activities were administered appropriately by ensuring that all students had equal access to technology and internet networks, and teachers have higher competence in the use of online applications (Cakiroglu et al., 2017a).

Several studies have been conducted concerning online assessment (e.g. Wulandari, Pratolo \& Junianti, 2019; Cakiroglu et al., 2017b; Prastiwi, Kartowagiran \& Susantini, 2020; Gaylard Baleni, 2015) which mainly dealt with perceptions and online assessment strategies conducted by teachers in a normal situation, however, this study specifically investigated teachers' assessment strategies during the Covid-19 pandemic in Indonesia. The study revealed provides contributions for teachers to broaden their horizons in conducting effective classroom assessments. Comprehending various difficulties in conducting assessments through online systems could help teachers to be aware of the challenges which may occur during the teaching-learning process. This study was conducted mainly to investigate the research questions such as (1) what online assessment strategies are employed by EFL teachers during the covid-19 pandemic, and (2) what challenges are encountered by EFL teachers in conducting online assessments during the covid-19 pandemic.

\section{METHODS}

This study used a qualitative research design with descriptive analysis. Observations, interviews, and documents were conducted to collect data for this study. Observations were conducted to collect the real implementation of the online assessment conducted by the teachers. Interviews were conducted to obtain further data related to implementation and challenges in conducting the online assessment. Moreover, document studies were carried out to gather the data related to the test types, scoring, and grading. Furthermore, the data were processed using descriptive analysis to examine the phenomena that occurred during the learning process in the Covid-19 pandemic. All teachers were interviewed through online communication 
media and observed them when they were conducted online learning by joining them in the classroom as passive participants in Zoom and Google Meet classes. All assessment documents used by the teachers were critically overseen to get the real pictures of the teachers' preparation and students' results as well as teachers' corrective feedback. The collected data were then categorized according to the appropriate category, and then analyzed descriptively, supported by various arguments based on multiple sources related to online assessments carried out by teachers during online learning. To ensure the reliability of the data, all data were triangulated by conducting a crossanalysis of all data collected from interviews, observations, and document studies. All the data collected were put in the right category and data which were collected from the observations were matched with the data collected from the interviews and the document studies.

\section{RESULTS AND DISCUSSION}

This study merely investigated the online assessment strategies employed by teachers during the Coronavirus pandemic. Moreover, this study also intended to reveal the challenges encountered by the teachers during the assessment administration. This study focused on comprehensively studying the online assessment strategies which were employed, and challenges encountered by EFL teachers in conducting online assessments during the covid19 pandemic. The results of the study were presented as the following Table 1.

TABLE 1 | Result of the Study

\begin{tabular}{|c|c|c|c|}
\hline Teacher & $\begin{array}{l}\text { Online } \\
\text { assessment } \\
\text { strategy }\end{array}$ & Challenges & Platform \\
\hline Teacher A & $\begin{array}{l}\text { online test } \\
\text { administration }\end{array}$ & $\begin{array}{l}\text { Slow internet network, expensive internet quota } \\
\text { prices, limited access to computer and smartphone } \\
\text { devices, poor ability in using digital technology }\end{array}$ & WhatsApp, Google Classroom \\
\hline Teacher B & $\begin{array}{l}\text { online test } \\
\text { administration }\end{array}$ & $\begin{array}{l}\text { Slow internet network, expensive internet quota } \\
\text { prices, limited access to computer and smartphone } \\
\text { devices, poor ability in using digital technology }\end{array}$ & WhatsApp, Google Classroom \\
\hline Teacher C & $\begin{array}{l}\text { online test } \\
\text { administration, } \\
\text { portfolio }\end{array}$ & $\begin{array}{l}\text { Slow internet network, expensive internet quota } \\
\text { prices, limited access to computer and smartphone } \\
\text { devices, poor ability in using digital technology }\end{array}$ & $\begin{array}{l}\text { WhatsApp, Google } \\
\text { Classroom, Google Forms }\end{array}$ \\
\hline Teacher D & $\begin{array}{l}\text { online test } \\
\text { administration, } \\
\text { portfolio }\end{array}$ & $\begin{array}{l}\text { Slow internet network, expensive internet quota } \\
\text { prices, limited access to computer and smartphone } \\
\text { devices, poor ability in using digital technology }\end{array}$ & $\begin{array}{l}\text { WhatsApp, Google } \\
\text { Classroom, Google Forms }\end{array}$ \\
\hline Teacher E & $\begin{array}{l}\text { online test } \\
\text { administration, } \\
\text { portfolio, and } \\
\text { self-assessment. }\end{array}$ & $\begin{array}{l}\text { Slow internet network, expensive internet quota } \\
\text { prices, limited access to computer and smartphone } \\
\text { devices, poor ability in using digital technology, } \\
\text { difficulty in conducting effective interaction }\end{array}$ & $\begin{array}{l}\text { WhatsApp, Google } \\
\text { Classroom, Google Forms, } \\
\text { google meet, zoom meeting }\end{array}$ \\
\hline Teacher F & $\begin{array}{l}\text { online test } \\
\text { administration, } \\
\text { portfolio, and } \\
\text { self-assessment. }\end{array}$ & $\begin{array}{l}\text { Slow internet network, expensive internet quota } \\
\text { prices, limited access to computer and smartphone } \\
\text { devices, poor ability in using digital technology, } \\
\text { difficulty in conducting effective interaction }\end{array}$ & $\begin{array}{l}\text { WhatsApp, Google } \\
\text { Classroom, Google Forms, } \\
\text { google meet, zoom meeting }\end{array}$ \\
\hline
\end{tabular}

Furthermore, during the interviews, most teachers explain that they encountered similar challenges which were mainly about slow internet connection, expensive internet quota prices, poor ability in technology, and difficulty in communicating effectively with their students. The challenges encountered by the teachers were similar in their forms but the degree of difficulty depended upon the geographical location, economical background, and experiences in using technology.

"well, online learning is a very new system for me. We live in a very remote area. I mainly teach and assess my students using WhatsApp. I send the tests to my students and my students send their answers through WhatsApp. Internet connection is very poor here and internet quota prices are expensive for my students". (Teacher A) "oh yes, online learning is definitely new for me. I am not really a technology-minded person. My friend told me to use the WhatsApp group to teach. In assessing my students, I just send a set of tests every end of learning unit and my students send their answers through WhatsApp after a few days because most of my students have no computer and only a few of them have a smartphone. They have to borrow it from their parents" (Teacher B)

"I teach my students using google classroom and WhatsApp. So, it is easier for me to assess my students which I send their answers through google classroom. Sometimes I send the test in the form of google form through WhatsApp. I collected my students' tasks in the form of a portfolio (Teacher C) 
"it is a challenge for me to teach and assess my students online. Sometimes I use to upload the test through google classroom and sometimes using WhatsApp, but it is difficult to monitor my students. I ask my students to file their tasks into a folder and they send them at once every week. (Teacher D)

"I use WhatsApp, sometimes google meet or zoom. I send the link of the tasks through chatbox and WhatsApp. My students send their answers through google form and then I collected to be my students' files for their portfolio. I ask my students to give their reflection on what their understanding through voice note on WhatsApp or directly when I ma using zoom or google meet". (Teacher E)

"Well, WhatsApp, Zoom, and google meet are really a big help for me. I assess my students using tests that I send through a google form, it is easier for me to file my students' work for their portfolio. I use zoom or google meet to get my students' self-reflection and provide them feedback"

Moreover, based on the document study prepared by the teachers in the form of lesson plans, it was found that teachers mainly utilized three forms of assessment strategy such as online test administration, portfolio, and selfassessment or reflection. Meanwhile, the online platforms used were zoom meeting, google meet, WhatsApp, and google classroom. The use of those platforms was varied because of their difficulty in internet connection.

In a broader sense, this study tried to reveal several solutions and suggestions for the sake of improvement of online learning and online assessment administration. This study found that teachers in this study understood that both conventional and online assessments were conducted to merely measure the learning outcomes of students. In this context, assessment is positioned as if it were a separate activity from the learning process (Widiastuti et al., 2020). Some teachers have a higher understanding that assessment is not only intended to measure learning outcomes but more importantly, how the assessment can be utilized to improve the competence of students in the learning process (Frunza, 2014). Therefore, the assessment needs to be conducted through three approaches, namely: (1) assessment of learning, (2) assessment for learning, and (3) assessment as learning. Assessment of learning aims to measure students' achievement of predetermined competencies. Assessment for learning allows the teachers to use the information on students' conditions to improve learning (Jordan, 2009), while assessment as learning allows students to see their learning achievements and progress to determine learning targets. Therefore, assessment of learning and assessment for learning are essential types of assessment for the enrichment of students' competence (Hargreaves, 2005).

Teachers in this study conducted the assessment strategies, namely (1) online test administration, (2) selfassessment, and (3) portfolio. Online test administration is an assessment by administering tests sent through WhatsApp, Google Classroom, Google Forms, and other applications. Students were assigned to answer tests provided by the teachers after the learning process took place. There was very limited supervision since teachers were unable to see the assessment activity directly, students answered from their own homes and then sent their answers to their teachers after completing the assessment. This indicates that teachers should have the ability to carry out various assessment strategies to ensure that students attain a higher level of competency (Arend, 2019)

A portfolio is another assessment conducted by teachers during online learning. Students were asked to answer several tasks and send them to their teachers. The tasks were based on the topics of the lesson taught by the teachers. The use of a portfolio model is an alternative to the distance learning process. A portfolio is a collection of student work that is arranged systematically and organized as a result of the learning efforts he has done within a certain period, for example, teachers put the assignments of the students into students' folders which showed gradual improvement of the students' achievement in learning. Therefore, it can be said that a portfolio assessment is an ongoing assessment based on a collection of information that shows the development of the students' competencies in a certain period (Karimi and Shafiee, 2014). In this case, the portfolio assessment assesses the work of individual learners at one time for each subject. Portfolios can be real products produced by students, such as articles, journals, or reflective notes that represent what students have done in one subject.

Another assessment strategy that most teachers carried out was self-assessment. Self-assessment is an assessment method that gives students the opportunity to take responsibility for their own learning. Therefore, teachers can start the self-assessment process by giving students the opportunity to validate their own thinking (Kirby and Merchant, 2020). Self-assessment is an assessment technique in which students are asked to assess themselves in relation to the status, process, and level of achievement of the competencies they have learned in certain subjects based on the criteria or references that were prepared. With selfassessment, students are trained to monitor and evaluate their own thoughts and actions and identify their own weaknesses and strengths to achieve the desired learning outcomes. The main objective of self-assessment is to support or improve learning processes and outcomes, so this assessment serves as an assessment that supports commonly used judgments (Ćukušić, Garača \& Jadrić, 2014).

Based on the interviews, teachers stated that in assessing students, there are several things that need to be considered by the teachers as follows: (1) assessment carried out by the teachers should not only be an assessment of learning but also an assessment for learning and assessment as learning; (2) assessment is directed to measure the achievement of basic competencies relevant to core Competencies; and (3) assessment uses the criteria reference, which is an assessment that compares the achievements of students with the specified competency criteria (Mantra, Astawa \& Widiastuti, 2018). Moreover, the results of the assessment should not be compared with the results of other students but should be compared with the mastery of specified competencies. The assessment should be carried out in a 
planned and continuous manner, and the results were then analyzed to determine the basic competencies that have been and which have not been mastered by students, as well as to determine the learning difficulties of students (Maba, 2018). The results of the assessment are analyzed to determine the follow-up, in the form of a remedial program for students with the achievement of competencies to ensure that students attain higher learning competencies.

There are many technical challenges and obstacles faced by teachers in conducting online assessments during this corona pandemic. Teachers found obstacles in adapting their conventional assessment practices to online systems that need extra knowledge to design and administer the assessment using communication technology (Alruwais, Wills \& Wald, 2018). Teachers should modify their form of assessment to suit the needs of the students and test types can be easily assessable accommodated by online applications and assessable easily by the students. Moreover, students faced various constraints on internet access which burden students in doing the learning process and assessment (Timmis et al., 2016). The challenges encountered by the teacher in conducting online learning and assessment varied in their forms. Most teachers mainly experienced the following challenges in conducting classroom assessment during the pandemic of Covid-19, they were slow internet network, expensive internet quota prices, limited access to computer and smartphone devices, poor ability in using digital technology, difficulty in conducting effective interaction.

At glance, the challenges encountered by the teachers were similar, however, every teacher experienced a different level of difficulty depending upon their geographical location, economical background, and abilities in using technology in teaching. Teachers and students who were located in rural areas where internet connection was very low, the learning interaction was hard to be established. In this situation, teachers relied on the WhatsApp application to send the assignment to their students. Students who were economically disadvantaged, they had to borrow smartphone from their parents or their neighbors. Meanwhile, those who were in the city could conduct the learning activities through zoom or google meet. Although they were able to communicate through zoom or google meet, they still found it difficult to communicate effectively.

Another difficulty encountered by teachers is providing feedback on the students' assessment results. Teachers found it difficult to communicate directly to students to explain students' problems in learning. Feedback is very important to be given to students to enhance their ability to achieve the predetermined learning competence stated in the learning curriculum (Widiastuti et al., 2019). Both written and oral feedback should be provided although the learning processes are conducted through online learning. In this study, written feedback was sometimes provided if the teachers have the time and opportunity to return their students' assignments. Short remarks in the form of short phrases were given such as "good', very good, excellent, good job and other similar phrases" when they were teaching using WhatsApp. Oral feedback was hardly given because teachers mainly spent their time delivering the learning materials when they were teaching using Zoom or Google Meet.

Assessment in the context of learning is a process of information gathering to measure the achievement of students' learning outcomes (Widiastuti et al., 2020). The assessment in this case should really be intended to assess students' learning outcomes which include aspects of attitudes, knowledge, and skills. An attitude assessment is carried out to obtain information that describes the behavior of students. Assessment of knowledge to measure the achievement of students' knowledge mastery. Meanwhile, skill assessment aims to measure the ability of students to implement knowledge to perform certain tasks. The spread of the massive corona pandemic has had a significant impact on the implementation of education in Indonesia (Abidah et al., 2020). The implementation of education during the Corona pandemic was carried out at home which required internet connection and learning applications to conduct the learning process and assessment.

The learning process is carried out by the teachers using an online learning model. It is a very different way of teaching. Mainly, the difference between conventional learning models and online learning models lies in the form of interaction between teachers and students, types of programs, the role of human resources, management, and technology. The tendency to transition from conventional face-to-face learning to contemporary learning based on elearning can be accessed by utilizing media, software devices, interactive multimedia, and internet networks without being limited by distance, space, and time (Abidah et al., 2020). Through communication applications, teachers can conduct multiple communications with the students.

The online learning model enables students to develop their independent learning. The dependence of students on teachers for face-to-face learning is very minimal because application such as Zoom and Google Meet allows teachers and students to communicate as if they were in a real classroom. However, in a remote area, sometimes limited face-to-face communication may take place when students experience difficulties in their learning activities or after completing certain learning units. To be the assessment process more effective, teachers are required to use an assessment model or alternative assessment rather than the assessment model that is usually done in conventional learning processes. This is because the online assessment is an assessment that is carried out using information technology and internet network, where the assessment can be done anywhere as long as the students have access to the internet network it is. However, teachers should utilize various assessment strategies in online learning (Gaytan \& McEwen, 2007).

Considering the types of the assessment strategies and problems encountered by the teachers, several things that should be pursued by the education institution to improve the quality of online learning and assessment, administration, among others: first, educational institutions must begin to improve facilities and infrastructure for supporting online learning, Learning Management System, 
and adequate supervision. Second, increasing the capacity of teachers in the implementation of online learning and assessment, and improving the ability of the teachers in using information technology. This is important because teachers should always update their knowledge, so the assessment of students can be done more varied. Third, the expansion of technology platform which supports the online learning and assessment activities.

Furthermore, teachers should continually make efforts to be more professional in carrying out online learning. Teachers are not only expected to be competent in planning the online assessment but they are also expected to be able to administer the assessment effectively using information and communication technology. Since most teachers found some difficulties in developing digital competence due to lack of prior knowledge as they are used to teach their students directly in a real classroom setting, therefore, continuous training is needed to improve their competence in conducting online learning and digital communication technology.

\section{CONCLUSION}

The online learning process applied in all learning institutions during the Covid-19 pandemic requires teachers to conduct various assessment models appropriate and support online learning. Several assessment strategies were applied in online learning which includes online-based assessments, portfolio assessments, and self-assessments. The online assessment conducted by the teachers during the Covid-19 outbreak has provided a change and challenges for the teachers to carry out the learning activity successfully. Moreover, teachers found difficulty in carrying out effective online assessments due to several obstacles and challenges encountered. Therefore, teachers should have the ability to adapt to their conventional teaching practices to online learning. Meanwhile, students should continually adapt their way of learning to keep up with learning materials given by the teachers through online communication technology. This study suggests that teachers should be provided with sufficient knowledge of online assessment and information technology to enable them to conduct the assessment properly to attain the predetermined assessment purposes and assessment objectives. Furthermore, other researchers are suggested to conduct more intensive studies on the implementation of online assessment and the challenges encountered by the teachers.

\section{ACKNOWLEDGEMENTS}

The authors would like to express sincere gratitude to all respondents especially those teachers who helped us in conducting this study. We would also like to thank the members of the English Language Education Study Program, the Faculty of Teacher Training Education, Mahasaraswati Denpasar University for their valuable help and support.

\section{REFERENCES}

Abidah, A. et al. (2020). The impact of covid-19 to indonesian education and its relation to the philosophy of "Merdeka Belajar". Studies in Philosophy of Science and Education, 1(1), pp. 3849. doi: 10.46627/sipose.v1i1.9.

Alruwais, N., Wills, G. and Wald, M. (2018). Advantages and challenges of using e-Assessment. International Journal of Information and Education Technology, 8(1), pp. 34-37. doi: 10.18178/ijiet.2018.8.1.1008.

Arend, B. D. (2019). Course assessment practices and student learning strategies in online courses. Online Learning, 11(4), pp. 3-17. doi: 10.24059/olj.v11i4.1712.

Baleni, Z. G. (2015). Online formative assessment in higher education: Its pros and cons. Electronic Journal of $e$ Learning (EJEL), 13(4), pp. 228-236.

Cakiroglu, U. et al. (2017a). Students' preferences in online assessment process: Influences on academic performances. Turish Online Journal of Distance Education, (January), pp. 132-142.

Cakiroglu, U. et al. (2017b). Students' prefe rences in online assessment process. Turish Online Journal of Distance Education, (January). 132-142.

Ćukušić, M., Garača, Ž. and Jadrić, M. (2014). Online selfassessment and students' success in higher education institutions, Computers and Education. 72, pp. 100109. doi: 10.1016/j.compedu.2013.10.018.

Frunza, V. (2014). Advantages and barriers of formative assessment in the teaching-learning activity. Procedia - Social and Behavioral Sciences, 114, pp. 452-455. doi: 10.1016/j.sbspro.2013.12.728.

Gamage, K. A. A., de Silva, E. K. and Gunawardhana, N. (2020). Online delivery and assessment during COVID-19: Safeguarding academic integrity. Education Sciences, 10(11), pp. 1-24. doi: 10.3390/educsci10110301.

Gaylard Baleni, Z. (2015). Online formative assessment in higher education: Its pros and cons. Electronic Journal of e-Learning, 13(4), pp. 228-236.

Gaytan, J. and McEwen, B. C. (2007). Effective online instructional and assessment strategies. American Journal of Distance Education, 21(3), pp. 117-132. doi: 10.1080/08923640701341653.

Hargreaves, E. (2005). Assessment for learning? Thinking outside the (black) box. Cambridge Journal of Education, 35(2), pp. 213-224. doi: 10.1080/03057640500146880.

Jordan, S. (2009). Assessment for learning: Pushing the boundaries of computer-based assessment. Practitioner Research in Higher Education, 3(1), pp. 11-19.

Karimi, M. N. and Shafiee, Z. (2014). Iranian EFL teachers' perceptions of dynamic assessment: Exploring the role of education and length of service. Australian Journal of Teacher Education, 39(8), pp. 143-162. doi: 10.14221/ajte.2014v39n8.10. 
Kearns, L. R. (2012). Student assessment in online learning: challenges and effective practices. Journal of Online Learning and Teaching (JOLT), 8(3), pp. 198-208.

Kirby, J. R. and Merchant, S. (2020). Assessment for learning and self-regulation. Oxford Research Encyclopedia of Education, 7(1), pp. 20-34. doi: 10.1093/acrefore/9780190264093.013.933.

Ma, Z. and Gao, P. (2010). Promoting learner autonomy through developing process syllabus-syllabus negotiation: The basis of learner autonomy. Journal of Language Teaching and Research, 1(6), pp. 901908. doi: 10.4304/jltr.1.6.901-908.

Maba, W. (2018). Conducting assessment instrument models for teacher competence, teacher welfare as an effort to enhance education quality. International Research Journal of Management, IT and Social Sciences, 5(3), pp. 46-52. doi: 10.21744/irjmis.v5i3.667.

Mantra, I. B. N. et al. (2019). Teachers' competences in dealing with instructional constraints to develop higher quality of learning. International journal of social sciences, (July). doi: 10.31295/ijss.v3n1.95.

Mantra, I. B. N., Astawa, I. N. and Widiastuti, I. A. M. S. (2018). Integrating innovative experiential learning in cyclic teaching sessions of English speaking classes. SOSHUM: Jurnal Sosial dan Humaniora, 8(2), pp. 185-190. doi: 10.31940/soshum.v8i2.992.

Prastiwi, M. S., Kartowagiran, B. and Susantini, E. (2020). Assessing using technology: Is electronic portfolio effective to assess the scientific literacy on evolution theory. International Journal of Emerging Technologies in Learning, 15(12), pp. 230-243. doi: 10.3991/ijet.v15i12.12227.

Robles, M. and Braathen, S. (2002). Online assessment techniques. Delta Pi Epsilon Journal, 44(1), pp. 3949. Available at: http://www.acousticslab.org/dots_sample/module2/R oblesAndBraathen2002.pdf.

Sewell, J. P., Frith, K. H. and Colvin, M. M. (2010). Online assessment strategies: A primer. Journal of Online Learning and Teaching (JOLT), 6(1), pp. 297-305.

Timmis, S. et al. (2016). Rethinking assessment in a digital age: Opportunities, challenges and risks. British Educational Research Journal, 42(3), pp. 454-476. doi: 10.1002/berj.3215.

Wang, T.-H. (2018). Developing a web-based assessment system for evaluating examinee's understanding of the procedure of scientific experiments. EURASIA Journal of Mathematics, Science and Technology Education, 14(5), pp. 1791-1801. doi: 10.29333/ejmste/85170.

Widiastuti, I. A. M. S. et al. (2019). Students' perception of assessment and feedback practices: Making learning visible. International Journal of Sustainability, Education, and Global Creative Economy (IJSEGCE), 2(1), pp. 1-8. doi: https://doi.org/10.1234/ijsegce.v2i1.49.
Widiastuti, I. A. M. S. et al. (2020). Dissonances between teachers' beliefs and practices of formative assessment in EFL classes. International Journal of Instruction, 13(1), pp. 71-84. doi: 10.29333/iji.2020.1315a.

Wulandari, A. T., Pratolo, B. W. and Junianti, R. (2019). Lecturers perceptions on portfolio as an assessment tool in English language testing. LEKSEMA: Jurnal Bahasa dan Sastra, 4(2), p. 179. doi: 10.22515/ljbs.v4i2.1988.

Conflict of Interest Statement: The authors declare that the research was conducted in the absence of any commercial or financial relationships that could be construed as a potential conflict of interest.

Copyright (C) 2021 Ida Ayu Made Sri Widiastuti, Ida Bagus Nyoman Mantra, Heru Sukoco \& Made Hery Santosa. This is an open-access article distributed under the terms of the Creative Commons Attribution License (CC BY). The use, distribution or reproduction in other forums is permitted, provided the original author(s) and the copyright owner(s) are credited and that the original publication in this journal is cited, in accordance with accepted academic practice. No use, distribution or reproduction is permitted which does not comply with these terms. 